\title{
DESIGN OF SHIP'S PERSONNEL POSITION MONITORING SYSTEM BASED ON LORA / GPS SHIELD USING DELPHI
}

\author{
Agus Setiyawan, Alexander Victor B, Arie Marbandi, Edy Widodo \\ D-3 Informatics Engineering, Indonesian Naval Technology College \\ www.sttal.ac.id
}

\begin{abstract}
The ship escort mechanism and system in KRI / KAL in reporting the position of the ship being guarded at this time is only limited to reports via radio communication equipment / HT. This caused the KRI / KAL Commander's decision to be reconfirmed manually between the ship's escort Personnel and the KRI / KAL Guard Officer. Therefore it is necessary to have a system that can monitor the position of ship escort personnel periodically by applying LoRa (Long Range) technology integrated with a GIS-based information system (Geographic Information System). The position monitoring system for ship escort personnel can send coordinate data from the Client transceiver device that is carried by the ship escort personnel periodically with the 915MHz LoRa TM protocol and receive the closest Gateway transceiver in KRI / KAL with the same frequency with an average time of two once a second transmits, the coordinate data received is stored in the application server database monitoring the position of ship escort personnel in the form of markers, so that the position of personnel is monitored periodically and can be immediately reported to the KRI / KAL Commander as decision maker. This system can also receive coordinate data from several Client transceiver devices.
\end{abstract}

Keywords: LoRa / GPS shield, ship personnel, GIS (Geographic Information System).

\section{INTRODUCTION}

\subsection{Background}

The task of escorting a ship is one of the tasks of the KRI / KAL Personnel based on the $\mathrm{KRI} / \mathrm{KAL}$ Commander's order to bring the ship and the person to the designated port / port, then the ship is brought to the base by being escorted or coupled with KRI / KAL, the task of escorting this ship carried out two to four KRI / KAL personnel and led by one officer equipped with weapons, HT communication equipment, safety devices, portable GPS and personal needs, in the implementation of the mechanism and system of ship escort at this time by reporting the position of the ship being periodically escorted via radio / HT in accordance with the request of the KRI Commander / KAL.

This caused the Commander's decision to be reconfirmed manually between the ship escort Personnel and the KRI / KAL Guard Officer while carrying out escort duty, a few years ago precisely on December 14, 2016 the Navy experienced a four-person escort from the KRI Layang-635 ship reportedly missing when escort a fishing boat the Philippine- flagged ship named Nurhana in the waters of Talaud,

Sulawesi, which entered Indonesian territory without complete documents. The four missing personnel were Letda Laut Faisal Dwi AR, Serda Mes Rizki Dwi Septianto, KLK Amo Dian Mahendra and KLD Isy Badnur Rohim.

From the description of the problem above, according to the author, it can be minimized by maximizing the combat capability of the KRI / KAL escort team by holding regular and gradual training and utilizing information technology systems, namely the existence of a system that can provide coordinate information from the escorted ship in real time so that its position can be monitored periodically, then the writer has an idea or an idea to make "DESIGN AND MONITORING OF SHIP GUARANTEE POSITION MONITORING SYSTEMS WITH LORA / GPS SHIELD USING DELPHI" This system is expected to be able to send data in the form of latitude longitude or the position of the personnel coordinating which are carrying out vessel escort duties so that their position is periodically monitored using DELPHI. from KRI / KAL. 


\subsection{Problem Formulation}

From the background description can be formulated a problem that is needed a device that can provide coordinate information from the escorted ship in real time so that its position can be monitored periodically?

\subsection{Research Purpose}

The purpose of this study was to design ship control personnel monitoring system with LoRa / GPS Shield for use in KRI / KAL. The system is expected to monitor the position of personnel in real time carrying out the ship's duties from $\mathrm{KRI} / \mathrm{KAL}$ to the command center periodically.

\subsection{Benefits of Research} follows:

The benefits of this research are as

a. For the $\mathrm{KRI} / \mathrm{KAL}$ Commander, assist in decision making and provide information on the position of the regulated ship in real time.

b. For the Naval Officer, it is easy to monitor the movement of the ship's current position through the equipment provided to the Ship's Personnel and assist in directing the movement of the ship under control.

c. For the ship's Personnel, it provides a sense of security as its position is monitored by $\mathrm{KRI} /$ KAL.

\section{LITERATURE REVIEW}

\subsection{LoRa (Long Range)}

LoRa is a wireless digital data communication technology developed by Cycleo from Grenoble, France and owned by Semtech in 2012. LoRa uses a modulation format using sub-Giga Hertz license-free radio frequency bands, the process produces stable frequency values, transmission can also use PSK ( Phase Shift Keying), FSK (Frequency Shift Keying).

The concept of the workings of LoRa refers to four main elements, namely the LoRa client which is equipped with modules, the LoRa gateway as a LoRa server, the Connection to Internet devices such as Modems and Wireless Speedy Routers and the Network server as a place to store applications and databases. The data received by the module in the LoRa client will be sent with the LoRa RF protocol and then the LoRa gateway as the receiver closest receiving data with the same frequency, LoRa gateway will send the data back to the Network server with Ethernet or TCP / IP protocol connected to the database and application as shown in Figure 1.

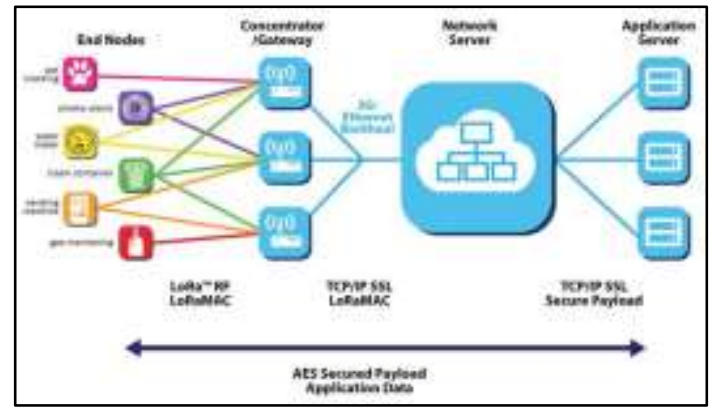

Figure 1 LoRa work system

\subsection{GPS (Global Positioning System).}

Global Positioning System or GPS devices are systems that can be used to inform users located on the surface of the earth based on satellites. Data sent from satellites is digital data, wherever the current position is, GPS can help indicate the position and direction of the GPS consists of three parts: the space segment, the control segment and the user segment. At present 24 satellites orbit at an altitude of $20,200 \mathrm{~km}$ over a 12-hour period and a slope of 55 degrees (every 12 hours the satellite returns at the same point), there are at least 6 satellites that can be monitored from earth wherever the position is. Satellite also sends time to users all over the world.

When determining the position of two dimensions (latitude, longitude) at least we need at least three satellites, whereas for three dimensional positions (latitude, longitude, and height) four satellites are needed. The more satellites you receive, the more accurate your position is. If our GPS device is in a room or around a tall building, the signal obtained will decrease so it will be difficult to determine its exact position. From the GPS device we can find out the existence of an object in the entire earth, both on land, sea and air as in Figure 2.

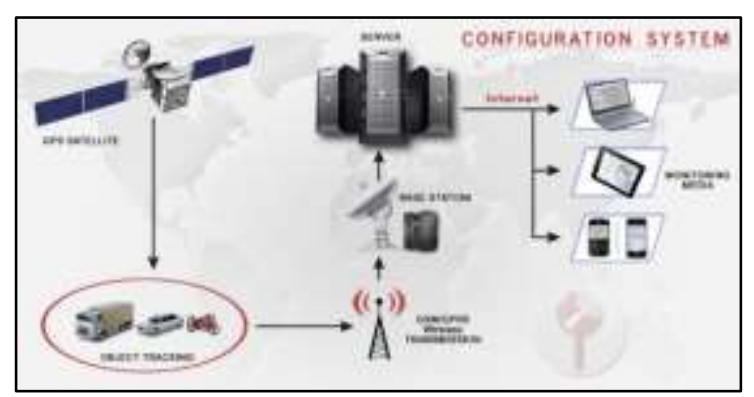

Figure 2 GPS tracker working system

\subsection{Sea Maps}

Sea Map is a projection of the earth or a part of the face of the earth which is depicted on a flat plane and used to sail at sea. Sea 
maps are made according to the original so that it can be used to sail in the sea or public waters. Sea map is one of the navigation tools for ship safety. In Indonesia the right to produce a sea map is Pushidrosal (Center for Hydrographic and Oceanographic Indonesian Navy) as in Figure 2.3, the sea map is divided into two types, namely:

a. Paper maps, maps printed on paper.

b. Electronic maps, digital maps in the form of shapefiles.

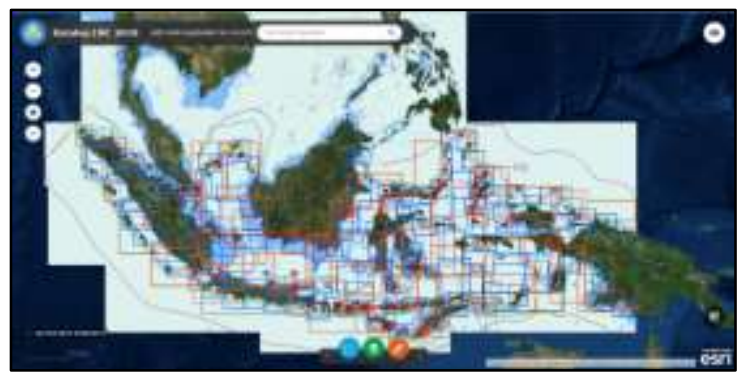

Figure 3 Electronic Marine Map

\section{RESEARCH METHOD}

\subsection{Research Design}

Design research as a guideline or research engineering in research that is useful as a guide to take strategies that produce research models or blueprints. This research uses the design method. "Design is a set of procedures to make the results of system analysis into a programming language to explain in detail how system components are implemented," (Pressman, 2002), while the definition of "building up is the creation of a new system or to change or modify an existing or partial system," (Pressman, 2002).

Design research using the model approach "System Development Life Cycle (SDLC) is a phased approach to analyzing and establishing system designs using cycles that are more specific to user activities," (Kendall \& Kendall, 2006). SDLC is also a center for developing efficient information systems. "SDLC consists of four stages, namely: planning and selection, analysis, design, implementation and operation," (Valacich \& George Hoffer, 2012). The stages in the SDLC model are shown in Figure 4.

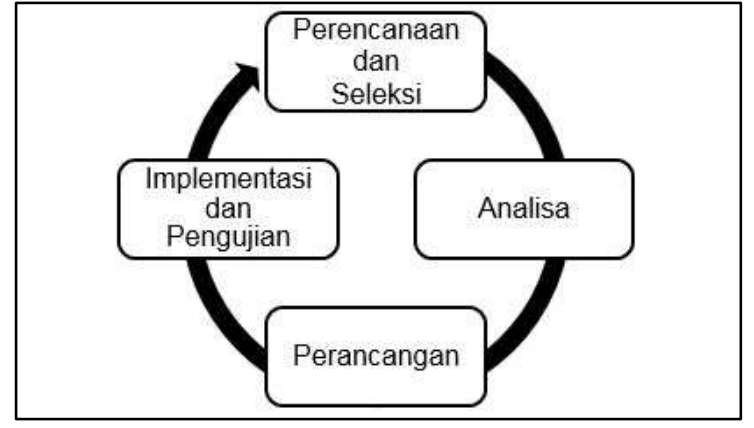

Figure 4 System Development Life Cycle research design

\subsection{Research Procedure}

Research procedures are a series of activities carried out by researchers periodically and systematically to pursue research objectives in order to better understand how to conduct research and the problems encountered as a basis for designing systems that are planned in the order of events. The procedure of the design research of the monitoring system of the position of ship escort personnel with LoRa / GPS Shield can be seen in Figure 5.

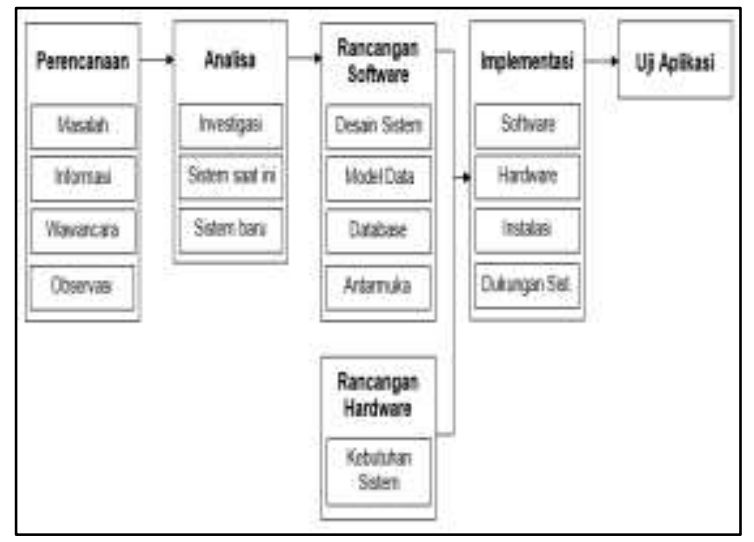

Figure 5 Research procedure

\subsection{Time and Place}

The final task study was conducted in the final semester of the Diploma-3 Technical School of the Naval Technology High School (STTAL) from July to December 2018. The venue for the research is being conducted at the Pushidrosal (Army AL Hydrography and Oceanography Center) and one of the KRI elements who performs sea patrols for system analysis. 


\subsection{Tools and Materials}

In carrying out this research, several tools and materials are needed to support the design and implementation of the monitoring system of ship escort personnel with a LoRa / GPS Shield. The tools and materials needed in conducting the research are as follows:
a. Computer / Laptop
b. LoRa Shield v95 $915 \mathrm{MHz}$
c. LoRa / GPS Shield v95 915MHz f
d. Arduino UNO Rev3
e. KMR-1.8 SPI TFT 128 * 160 display
f. USB cable type A / B Standard USB 2.0
g. Embarcadero Delphi
h. XAMPP

\subsection{Research Design}

Figure 6 is a general description of the overall system of personnel equipped with LoRa / GPS Shield as a Client transceiver in carrying out ship escort duties. As long as the device is on, the Client transceiver will send coordinate data with the LoRa TM protocol at a frequency of $915 \mathrm{MHz}$ and will be received by the Gateway transceiver on the same frequency, the Gateway transceiver is connected to a system that has been installed on a PC via a USB port, data is received periodically will be stored in the database server then the application will display the position of the Client transceiver in real time and can be easily monitored from KRI / KAL.

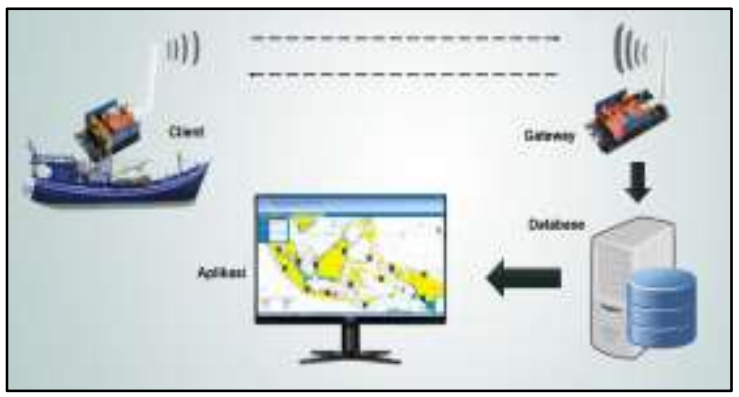

Figure 6: Overview

\subsection{System Design}

According to (John Burch and Garry Grudnitski, 1986), "system design can be determined as drawing and sketching or arranging separate elements into one, all working together." From this definition it can be concluded that the system design is the stage of drawing, planning and making to unite several separate elements in a unified system to clarify the system.

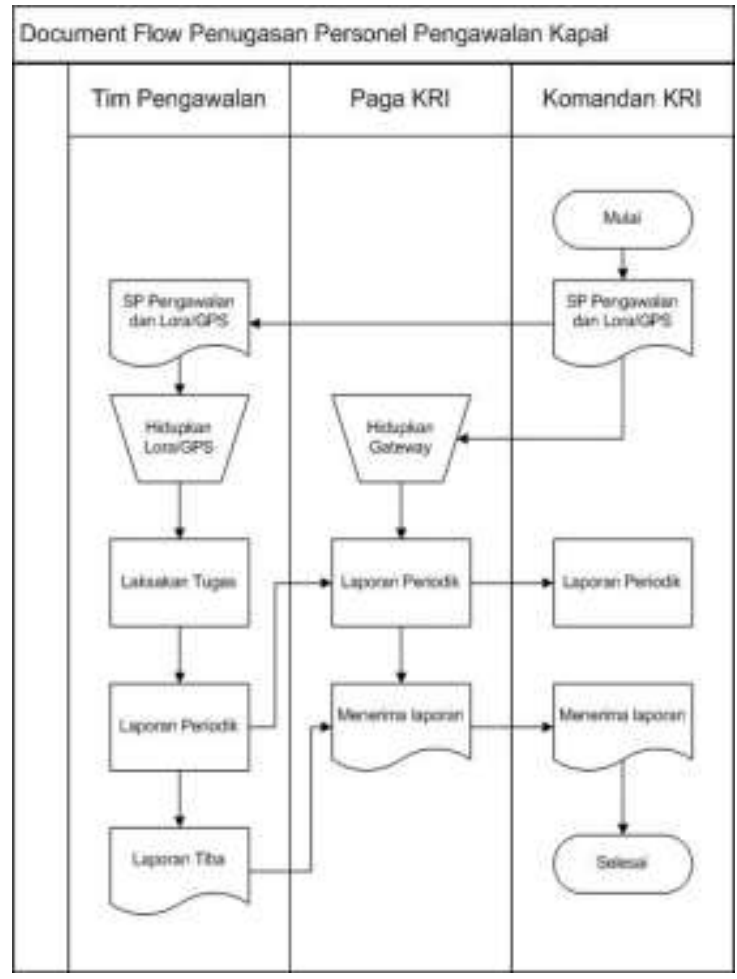

Figure 7 Document Flow assignment of ship escort personnel

Figure 7 is a Document Flow chart showing the flow of documents between parts in the system logically. Can describe each part of the organization involved in processing documents in the processes undertaken.

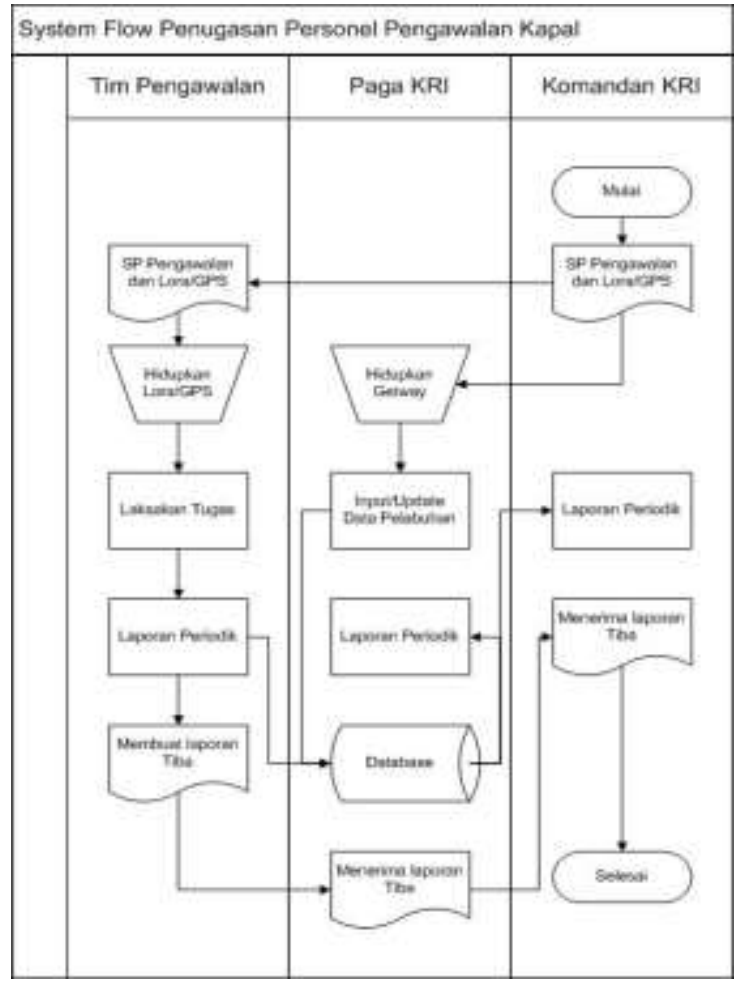

Figure 8 System Flow assignment of ship control personnel 
Figure 8 is the System Flow of the system to be built. System Flow is not much different from Document Flow, it's just that the process is more computerized.

\subsection{Data Collection}

The methods used to collect data in this research system are:

a. The method of observation, namely by observing directly how the activities in $\mathrm{KRI} / \mathrm{KAL}$ in the context of the inspection of the ship to the process of escorting the ship to be brought to the nearest port and the process of assigning its escort personnel.

b. Literature method, the primary source of this study is the LoRa / GPS Shield module which is used to transmit GPS coordinate data in real time, secondary sources in the form of digital maps in the form of shapefiles are used to convert GPS coordinate data into the system.

c. The interview method, which was given to the KRI Commander as the decision maker, the Guard Officer as the person in charge of the KRI / KAL movement and personnel who were assigned to carry out the escort duty as resource persons.

\subsection{Data Processing}

In the data processing procedure the monitoring system of the position of ship escort personnel with LoRa / GPS Shield consists of a number of data processing operations in the following sequence. First is the GPS data retrieval which requires at least three satellites, each satellite provides a unique signal that contains information about the orbit parameters and the accurate time when the signal was sent.

The sequence in the procedure of the next data processing is the coordinate data that has been received by GPS will be transmitted using LoRa (Long Range) technology using the FM modulation format sub-gigahertz radio frequency band license free, with the same frequency wave then the data will be received by the Gateway transceiver during in range.

The next sequence of coordinate data that has been received by the Gateway Transceiver will be managed by a DBMS (Database Management System) which functions to determine how the data is organized, stored, modified and retrieved, this software also applies the mechanism of data security, data usage together, consistency data and so on. Next coordinate data is converted by the system into spatial data contained on digital maps.

\section{ANALYSIS AND DISCUSSION}

\subsection{Analysis of Information Systems}

In carrying out the task of escorting the ship requires a new method of monitoring the position of personnel who are carrying out the task of escorting the ship by implementing a LoRa / GPS technology system integrated with a GIS-based information system (Geographic Information System) as in Figure 4.1, by knowing the position of personnel in real time through the LoRa / GPS Shield tool that is converted to a GIS-based information system on a digital map, the position of personnel can be immediately reported to the KRI / KAL Commander as policy maker for the task.

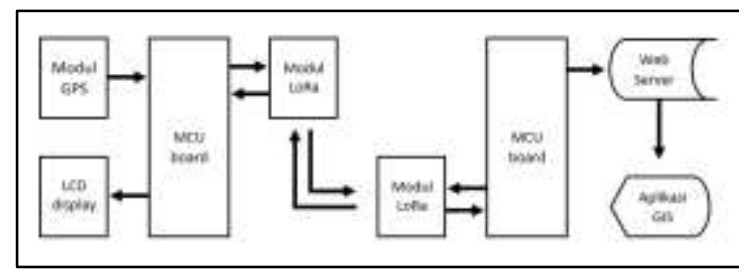

Figure 9 Schematics of information systems

\subsection{Software and Hardware Analysis}

To get the position coordinate data of personnel carrying out the task of escorting the ship the author uses a LoRa / GPS Shield v95 $915 \mathrm{MHz}$ hardware module as the Client side of the transceiver. In the GPS section, using the Quectel L80-M39 GPS based on MTK MT3339 is designed for applications that require GPS information, equipped with KMR-1.8 SPI 128 * 160 TFT as display output.

To receive coordinate data from the Transceiver Client, I use the LoRa Shield v95 $915 \mathrm{MHz}$ hardware as the gateway side of the transceiver. This shield uses the LoRaTM modulation technique patented by Hope RF. LoRaTM also provides significant advantages in blocking and selectivity in conventional modulation techniques, settlement between ranges, immune disorders and energy consumption. The system hardware requirements are as shown in Figure 10.

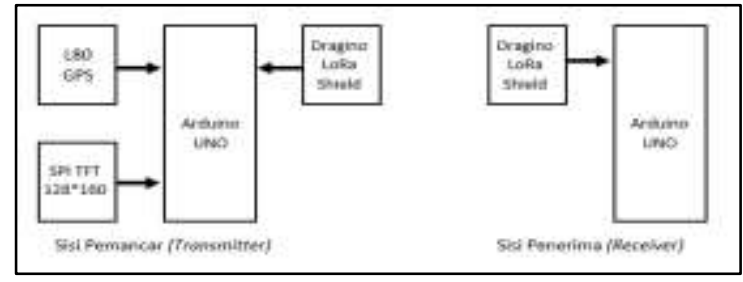


Figure 10 Schematic of Client transceiver and Gateway transceiver

In making the application of the monitoring system of ship escort personnel position with LoRa / GPS Shield, the writer uses Arduino IDE software with $C$ programming language to program hardware and script code with Pascal programming language from Embarcadero Delphi XE8 software.

\subsection{Data Needs Analysis}

Data obtained from the GPS L80 Quectel embedded in the LoRa / GPS Shield in the form of \$ GPRMC data is then processed and retrieved the necessary data in the form of coordinates and speed with float data types, date and time data integer data types after that data is converted to string data types so into a data packet that is ready to be sent with LoRa wirelles, after the data is sent it will be received by the Gateway transceiver and converted by the application to be stored on a database server.

Other data in the application system for monitoring the position of ship escort personnel is a digital map which is a product of Pushidrosal. Digital map functions as conversion of coordinate data that exists on the database server so that it can be easily read by the user, the map provided by Pushidrosal is a digital map with the JPG / JPEG extension but to be implemented in this system the map must first be converted to the GeoTIFF format.

Software that can process GeoTIFF data formats include ArcGIS, ArcView, Maplnfo, Er Mapper, Global Mapper. This system uses Global Mapper software, while the process of converting maps from JPG / JPEG to GeoTIFF format is shown in Figure 11.

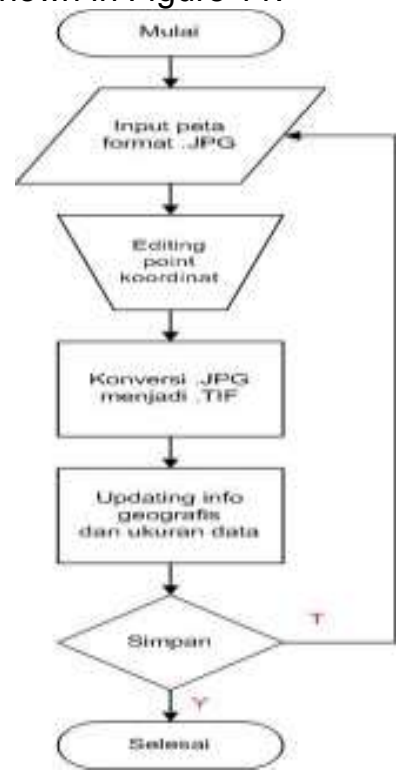

Figure 11 Flowchart digital map conversion process

\subsection{Hardware Implementation}

In implementing hardware in the monitoring system of ship escort personnel with LoRa / GPS Shield, this includes the preparation of hardware which is divided into two series, namely the Client transceiver and the Gateway transceiver.

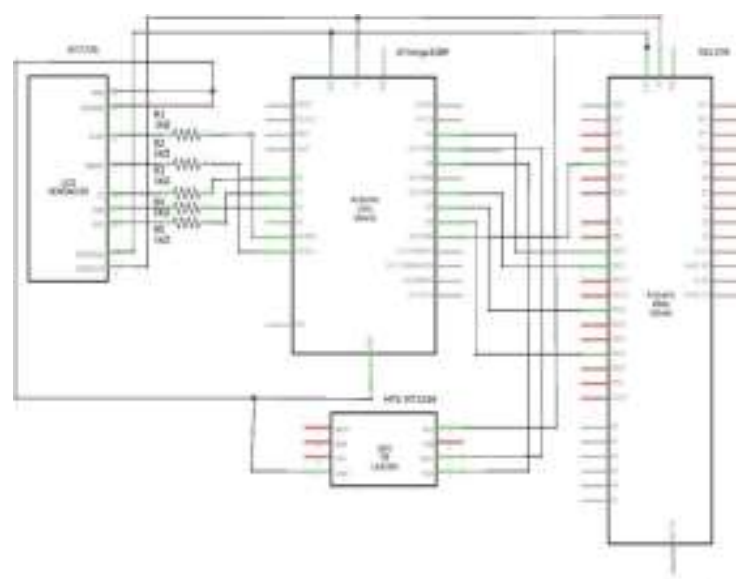

Figure 12 Client side transceiver network

Figure 12 is a series of Client side transceivers as a whole. This system consists of a LoRa / GPS Shield v95 915Mhz module which is connected to Arduino UNO Rev3. The output of this tool is coordinate data obtained from the GPS L80-M39 Quectel based on MTK MT3339 which will then be displayed via SPI TFT $128 * 160$ and transmitted with $915 \mathrm{MHz}$ frequency radio waves, implementation of the tool as in Figure 13.

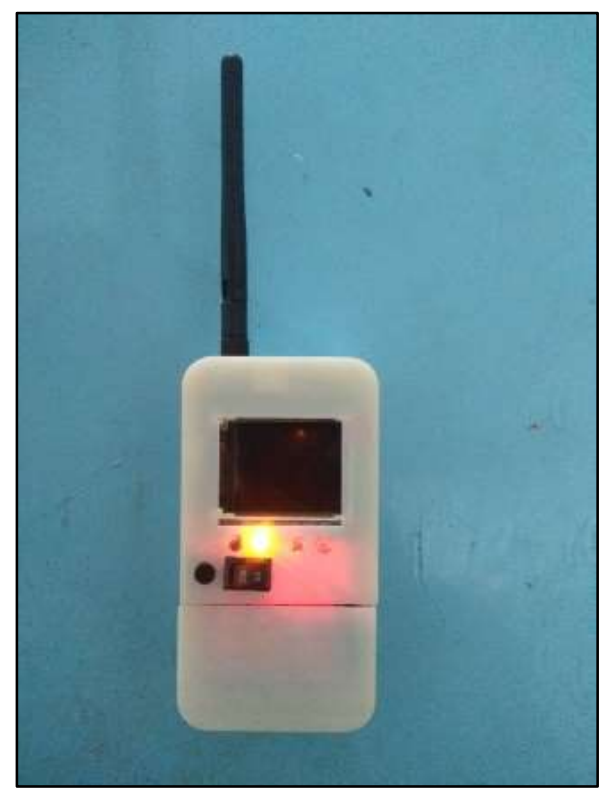

Figure 13 Implementation of the Client transceiver tool 


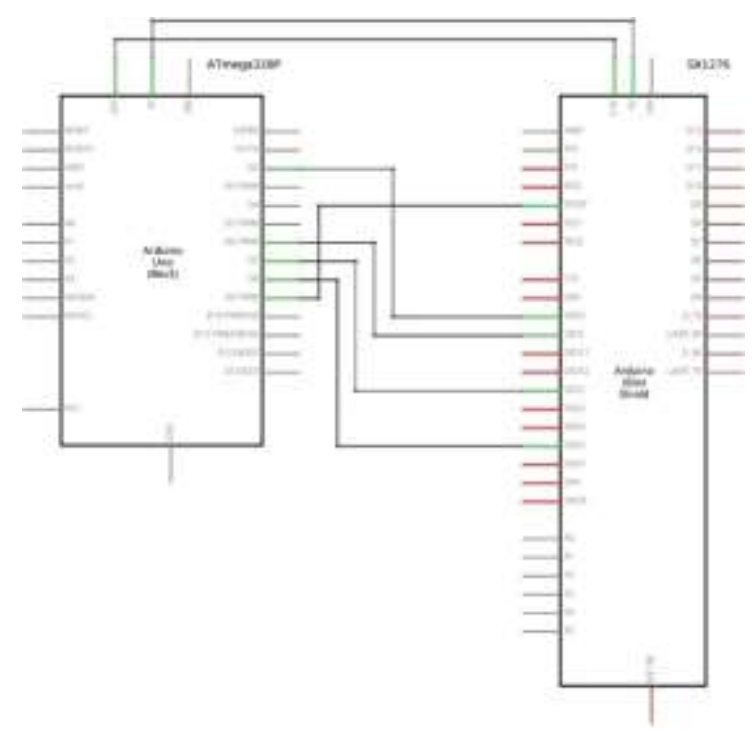

Figure 14 Gateway transceiver side chain

Figure 14 is a side series of Gateway transceiver systems as a whole. This system consists of a LoRa Shield v95 $915 \mathrm{Mhz}$ that is connected to Arduino UNO Rev3 functions to receive coordinate data sent from the Client transceiver with a frequency of $915 \mathrm{Mhz}$, then the device is connected with a USB 2.0 type A / $B$ cable to the computer's USB port.

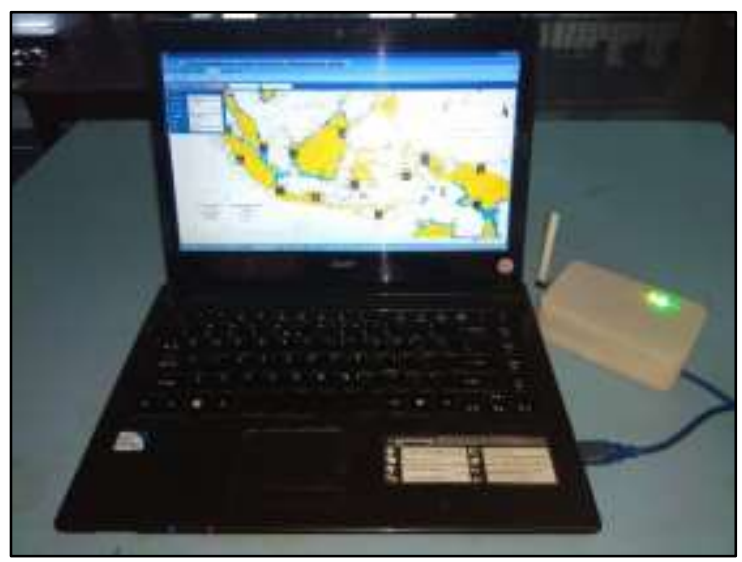

Figure 15 Implementation of the Gateway transceiver tool

Figure 15 is the output of the coordinate data obtained from the Client transceiver which will then be stored in a database server and the application for monitoring the position of the ship escorting pontiff will display the coordinates in the form of markers.

\subsection{Software Implementation}

Implementation of the monitoring system for the position of ship escort personnel with this LoRa / GPS Shield software used can be seen in Table.
Table Support software

\begin{tabular}{|c|c|c|}
\hline No & Name & Name \\
\hline 1 & $\begin{array}{l}\text { Sistem } \\
\text { Operasi }\end{array}$ & 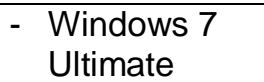 \\
\hline 2 & Data Base & - MySql \\
\hline 3 & $\begin{array}{l}\text { Program } \\
\text { Software }\end{array}$ & $\begin{array}{ll}\text { - } & \text { Embarcadero } \\
\text { Delphi XE8 } \\
\text { - } & \text { Arduino IDE }\end{array}$ \\
\hline 4 & Protocol & $\begin{array}{ll}- & \text { NMEA } 0183 \\
\text { - } & \text { LoRaTM } \\
\text { - } & \text { Serial USB }\end{array}$ \\
\hline
\end{tabular}

The Flowchart vessel monitoring personnel monitoring system with LoRa / GPS can be seen in Figure 16.

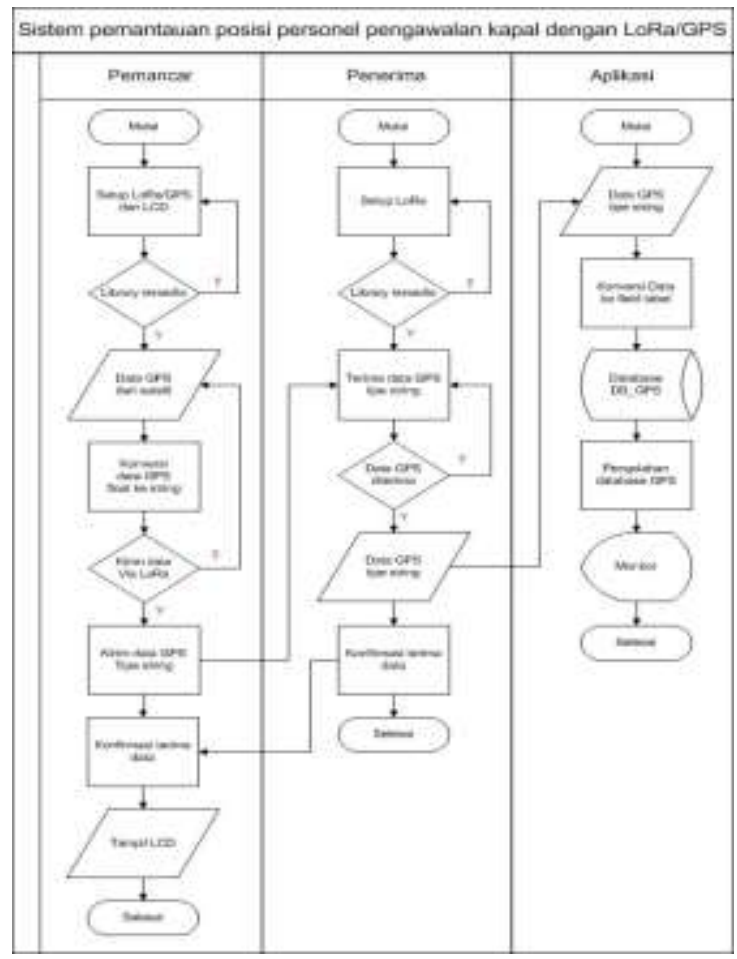

Figure 16 Flowchart monitoring system for ship escort positions

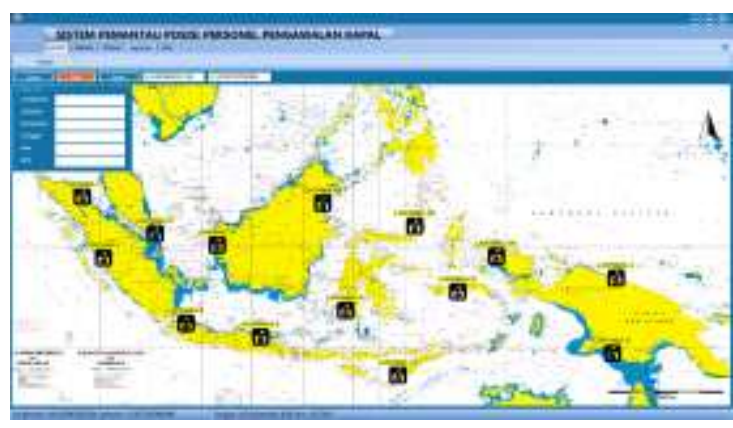

Figure 17 Database connected system form menu

After the application is connected to the database, the application will display a system menu in the form of a map of the Unitary Republic of Indonesia from Sabang to Merauke in the form of GeoTIFF containing information 
on the location of all Navy bases under the ranks of Koarmada as shown in Figure 17.

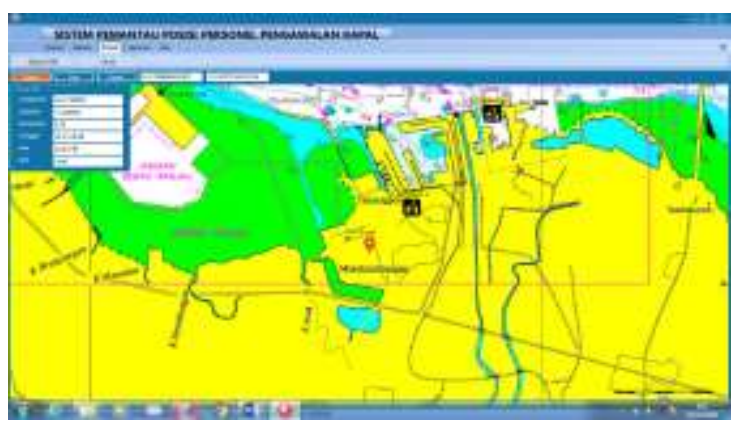

Figure 18 Process menu form

Figure 18 if the coordinate data has been received by the Gateway transceiver, it will display the Client transceiver position data on the GPS data form on the upper left, the data is automatically stored periodically in the datatps table database and displays the coordinate data in the form of markers on the map.

\subsection{Database Implementation}

Database implementation is an effort to build a physical database that is placed in a computer storage disk (disk) with the help of a DBMS, this stage begins by transforming the data model that has been completed to create a database structure in accordance with the selected DBMS, in the research of personnel position monitoring systems escorting ships with LoRa / GPS Shield uses MySQL as a database server.

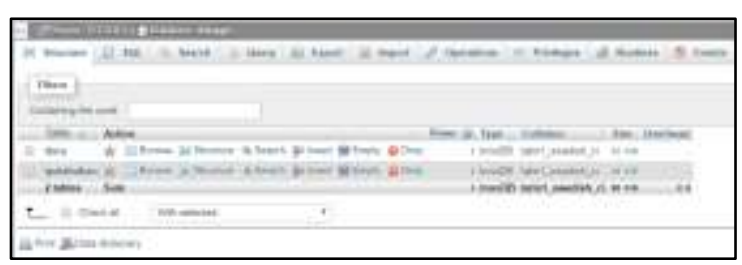

Figure 19 Implementation of gps data database

Description of Figure 19

Database name : datagps

Function : Store data monitoring system position of ship escort personnel.

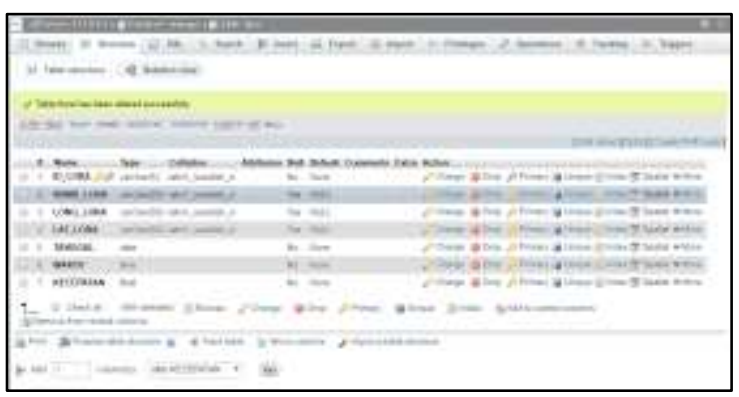

Figure 20 Implementation of lora data table
Remarks 20

Table name : tlora

Primary key : ID_LORA

Function : Save data from the Client transceiver periodically.

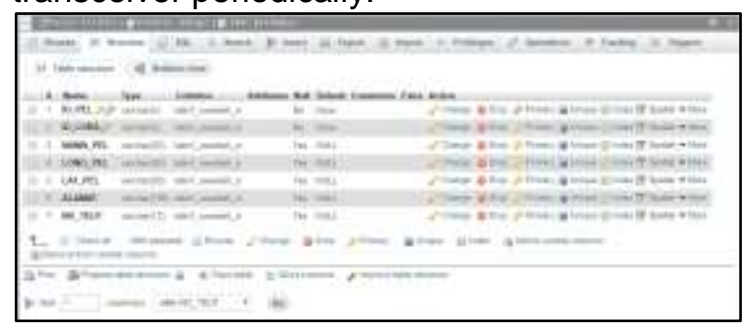

Figure 21 Implementation of the port data table

Image Caption 21

Table name: port

Primary key: ID_PEL

Function: Save the port data of operator input.

\begin{tabular}{|c|c|}
\hline 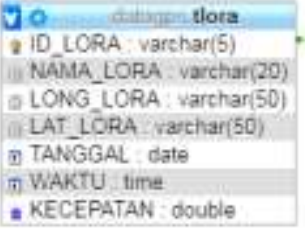 & 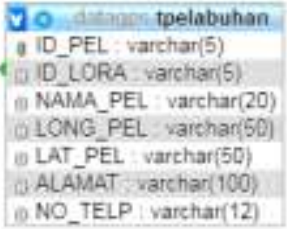 \\
\hline
\end{tabular}

Figure 22 Datagps database relations

Image Caption 22

Main table : tlora

The second table : port

Relationship : One to Many

Connection : ID_LORA (FK ID_LORA in port)

\subsection{Hardware Testing}

LoRa / GPS Shield v95 915Mhz test results as a client side transceiver using Arduino IDE serial monitor software can be seen as in Figure 23 data obtained in the form of latitute, longtitute, speed, date, time and name of the device in the form of a data string with a length of 51 Successful characters are sent to the Gateway transceiver.

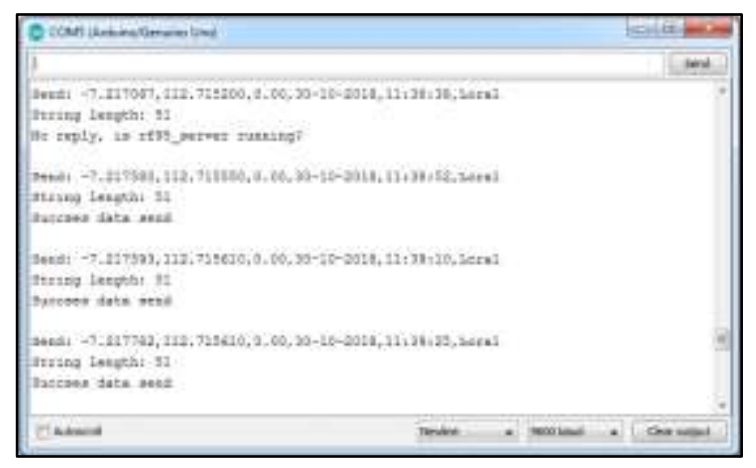

Figure 23 LoRa / GPS Client transceiver output data in Arduino IDE 
KMR-1.8 SPI TFT display test results as shown in Figure 24 data displayed in the form of latitute, longtitute, speed, date, time and name of the device.

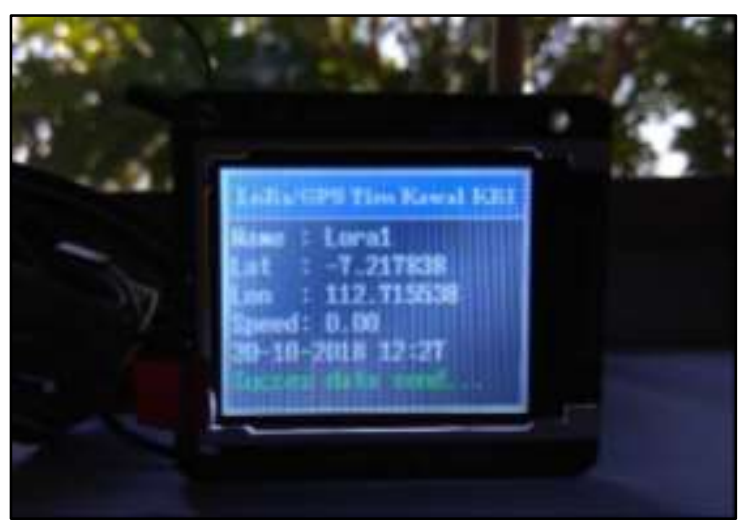

Figure 24 Testing on the KMR-1.8 SPI TFT display

The LoRa v95 915Mhz test results as a Gateway transceiver using Arduino IDE serial monitor software can be seen as in Figure 25 data received in the form of latitute, longtitute, speed, date, time and name of the device in the form of a string of data with a length of 51 characters received by Gateway transceiver.

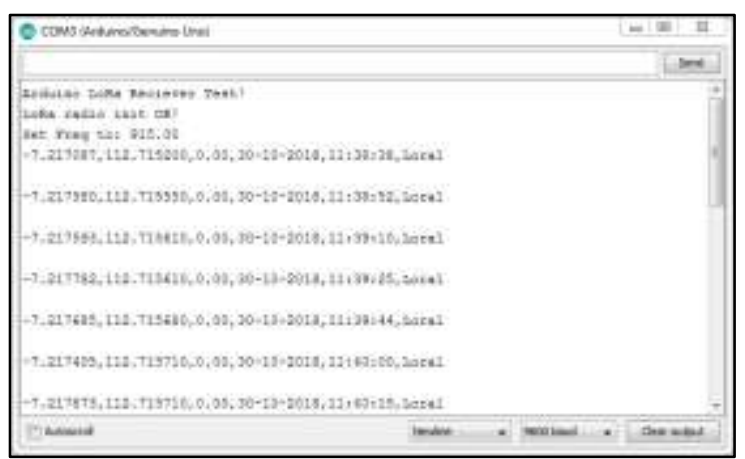

Figure 25 Gateway transceiver output data in Arduino IDE

\subsection{Purpose of Software}

Software testing is the most important thing that aims to find out the design results that have been made and find errors / bugs in applications that are built in the execution process. Software testing as in Table.

Software Testing Table

\begin{tabular}{|c|c|c|c|c|c|c|}
\hline $\begin{array}{c}\text { N } \\
\text { O }\end{array}$ & $\begin{array}{c}\text { PROGR } \\
\text { AM }\end{array}$ & TARGET & INPUT & $\begin{array}{c}\text { IDEAL } \\
\text { OUTPUT }\end{array}$ & $\begin{array}{c}\text { REAL } \\
\text { OUTP } \\
\text { UT }\end{array}$ & $\begin{array}{l}\text { STAT } \\
\text { US }\end{array}$ \\
\hline $\mathbf{1}$ & $\mathbf{2}$ & $\mathbf{4}$ & $\mathbf{5}$ & $\mathbf{6}$ & $\mathbf{7}$ & $\mathbf{8}$ \\
\hline 1 & $\begin{array}{l}\text { Connecti } \\
\text { on } \\
\text { database }\end{array}$ & $\begin{array}{l}\text { Connected } \\
\text { with } \\
\text { database } \\
\text { server. }\end{array}$ & $\begin{array}{l}\text { Port } \\
\text { patabase } \\
\text { password }\end{array}$ & $\begin{array}{l}\text { Able } \\
\text { connected } \\
\text { with } \\
\text { database }\end{array}$ & $\begin{array}{l}\text { Connect } \\
\text { ion } \\
\text { success }\end{array}$ & $\begin{array}{l}\text { Succes } \\
\text { s }\end{array}$ \\
\hline
\end{tabular}

\begin{tabular}{|c|c|c|c|c|c|c|}
\hline $\begin{array}{l}\mathbf{N} \\
\mathbf{O}\end{array}$ & $\begin{array}{c}\text { PROGR } \\
\text { AM }\end{array}$ & TARGET & INPUT & $\begin{array}{l}\text { IDEAL } \\
\text { OUTPUT }\end{array}$ & $\begin{array}{c}\text { REAL } \\
\text { OUTP } \\
\text { UT }\end{array}$ & $\begin{array}{c}\text { STAT } \\
\text { US }\end{array}$ \\
\hline 1 & 2 & 4 & 5 & 6 & 7 & 8 \\
\hline 2 & \begin{tabular}{|l} 
Input \\
data \\
harbour
\end{tabular} & $\begin{array}{l}\text { Saved in } \\
\text { database } \\
\text { MySQL. }\end{array}$ & $\begin{array}{l}\text { Name pel } \\
\text { Congitute } \\
\text { Latitute } \\
\text { Address } \\
\text { No telp }\end{array}$ & $\begin{array}{l}\text { Able saved } \\
\text { in } \\
\text { database... }\end{array}$ & \begin{tabular}{|l|} 
Success \\
to save \\
data
\end{tabular} & $\begin{array}{l}\text { Succes } \\
\text { s }\end{array}$ \\
\hline 3 & $\begin{array}{l}\text { Input } \\
\text { map }\end{array}$ & $\begin{array}{l}\text { Display } \\
\text { map of } \\
\text { inputan }\end{array}$ & $\begin{array}{l}\text { Map } \\
\text { xxtension } \\
\text { tif atau } \\
\text { shp }\end{array}$ & $\begin{array}{l}\text { Able display } \\
\text { map as } \\
\text { extension } \\
\text { tif atau .shp }\end{array}$ & $\begin{array}{l}\text { Success } \\
\text { update } \\
\text { map }\end{array}$ & $\begin{array}{l}\text { succes } \\
\text { s }\end{array}$ \\
\hline 3 & $\begin{array}{l}\text { Edit data } \\
\text { harbour }\end{array}$ & $\begin{array}{l}\text { Edit data } \\
\text { saved in } \\
\text { database. }\end{array}$ & $\begin{array}{l}\text { Name pel } \\
\text { Longitute } \\
\text { Latitute } \\
\text { Address } \\
\text { No telp }\end{array}$ & $\begin{array}{l}\text { Able edit } \\
\text { data that } \\
\text { saved in } \\
\text { database. }\end{array}$ & \begin{tabular}{|l|} 
Success \\
edit data
\end{tabular} & $\begin{array}{l}\text { Succes } \\
\text { s }\end{array}$ \\
\hline 4 & \begin{tabular}{|l|} 
Delete \\
data \\
harbour
\end{tabular} & \begin{tabular}{|l|} 
Delete \\
data saved \\
in \\
database.
\end{tabular} & $\begin{array}{l}\text { Name } \\
\text { harbour } \\
\text { Longitute } \\
\text { Latitute } \\
\text { Address } \\
\text { No telp }\end{array}$ & $\begin{array}{l}\text { Able delete } \\
\text { data in } \\
\text { database. }\end{array}$ & \begin{tabular}{|l|} 
Success \\
delete \\
data
\end{tabular} & $\begin{array}{l}\text { Succes } \\
\text { s }\end{array}$ \\
\hline & \begin{tabular}{|l} 
Setup \\
Tools \\
Gateway \\
transceiv \\
er
\end{tabular} & $\begin{array}{l}\text { Connected } \\
\text { with } \\
\text { database } \\
\text { and Save } \\
\text { data from } \\
\text { LoRa/GPS }\end{array}$ & $\begin{array}{l}\text { Port } \\
\text { Baudrate }\end{array}$ & \begin{tabular}{|l} 
Display and \\
Save data \\
Koordinat \\
baru atau \\
perubahan \\
data from \\
LoRa/GPS
\end{tabular} & \begin{tabular}{|l|} 
Able \\
save and \\
display \\
position \\
LoRa/G \\
PS in \\
betuk \\
tanda \\
icon
\end{tabular} & $\begin{array}{l}\text { Succes } \\
\mathrm{S}\end{array}$ \\
\hline 6 & $\begin{array}{l}\text { Display } \\
\text { data track }\end{array}$ & $\begin{array}{l}\text { Display } \\
\text { track from } \\
\text { data } \\
\text { LoRa/GPS }\end{array}$ & $\begin{array}{l}\text { Longitude } \\
\text { Latitude } \\
\text { Kecepatan } \\
\text { Date } \\
\text { Time } \\
\text { Name }\end{array}$ & $\begin{array}{l}\text { Display } \\
\text { position } \\
\text { LoRa/GPS } \\
\text { from } \\
\text { selurah data } \\
\text { that saved }\end{array}$ & $\begin{array}{l}\text { Able } \\
\text { display } \\
\text { track } \\
\text { position } \\
\text { LoRa/G } \\
\text { PS } \\
\text { (trackin } \\
\text { g) }\end{array}$ & $\begin{array}{l}\text { Succes } \\
\mathrm{s}\end{array}$ \\
\hline 7 & \begin{tabular}{|l} 
Delete \\
data GPS
\end{tabular} & $\begin{array}{l}\text { Delete } \\
\text { data in in } \\
\text { database. }\end{array}$ & $\begin{array}{l}\text { Name } \\
\text { Longitute } \\
\text { Latitute } \\
\text { Kecepatan } \\
\text { Date } \\
\text { Time } \\
\end{array}$ & $\begin{array}{l}\text { Able delete } \\
\text { data GPS in } \\
\text { database. }\end{array}$ & \begin{tabular}{|l|} 
Success \\
delete \\
data
\end{tabular} & $\begin{array}{l}\text { Succes } \\
\mathrm{s}\end{array}$ \\
\hline & $\begin{array}{l}\text { Display } \\
\text { info } \\
\text { aplikasi }\end{array}$ & \begin{tabular}{|l} 
Display \\
keteragan \\
informasi \\
sistem
\end{tabular} & & $\begin{array}{l}\text { Display } \\
\text { informasi } \\
\text { sistem }\end{array}$ & \begin{tabular}{|l|} 
Able \\
display \\
informa \\
si \\
aplikasi
\end{tabular} & $\begin{array}{l}\text { Succes } \\
\mathrm{s}\end{array}$ \\
\hline
\end{tabular}

\subsection{Integrated System Testing}

Testing the position monitoring system of ship escort personnel with integrated LoRa / GPS can be carried out after all hardware and software components that support the system 
process have been completed and installed correctly, testing on this system uses an open space area testing method to test the capability of the tool and testing multi client to test the system by receiving coordinate data from several Client transceiver devices.

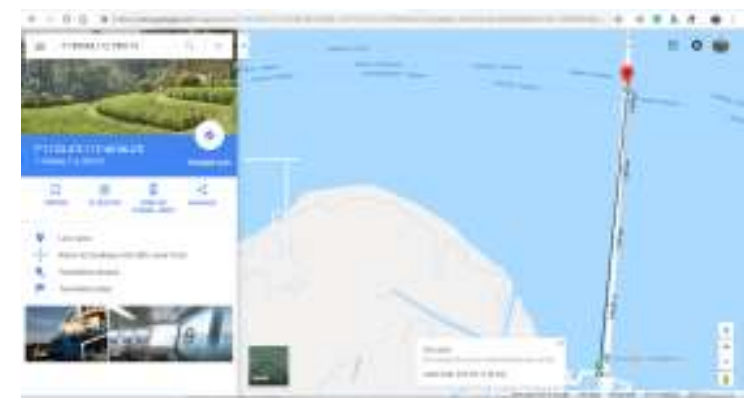

Figure 26 Testing your range with Google Maps

Figure 26 shows the starting point of testing the system at latitute coordinates = 7.208268 and longitute $=112.778240$ and the last point of data was successfully sent from the Client transceiver with latitude coordinates $=-7.189565$ and longitude $=112.780110$ with the Gateway transceiver received. the range of receipt of Client transceiver data from the starting point to the end point as far as $2.09 \mathrm{Km}$ using the help of Google Maps, in general the testing of the open space area system goes as expected, data from the Client transceiver can be sent to the Gateway transceiver periodically but it cannot be ascertained how much time is still needed for one time sending data even though this test is limited to three seconds from the Transceiver Client program to receive a confirmation message again that the data has been sent.

\section{Multi-client Testing Table}

\begin{tabular}{|c|r|r|l|l|l|l|}
\hline Kd & Latitute & Longitute & speed & Date & Time & Name \\
\hline 1 & -7.189565 & 112.780110 & 0.00 & $25-11-201$ & $12: 58: 15$ & LoRa1 \\
\hline 2 & -7.217782 & 112.715610 & 0.00 & $27-11-201$ & $17: 05: 58$ & LoRa2 \\
\hline 3 & -7.189565 & 112.780110 & 0.00 & $25-11-201$ & $12: 58: 15$ & LoRa1 \\
\hline 4 & -7.217782 & 112.715610 & 0.00 & $27-11-201$ & $17: 05: 58$ & LoRa2 \\
\hline 5 & -7.217782 & 112.715610 & 0.00 & $27-11-201$ & $17: 05: 58$ & LoRa2 \\
\hline 6 & -7.189565 & 112.780110 & 0.00 & $25-11-201$ & $12: 58: 15$ & LoRa1 \\
\hline 7 & -7.217782 & 112.715610 & 0.00 & $27-11-201$ & $17: 05: 58$ & LoRa2 \\
\hline 8 & -7.189565 & 112.780110 & 0.00 & $25-11-201$ & $12: 58: 15$ & LoRa1 \\
\hline 9 & -7.189565 & 112.780110 & 0.00 & $25-11-201$ & $12: 58: 15$ & LoRa1 \\
\hline 10 & -7.189565 & 112.780110 & 0.00 & $25-11-201$ & $12: 58: 15$ & LoRa1 \\
\hline 11 & -7.217782 & 112.715610 & 0.00 & $27-11-20117: 05: 58$ & LoRa2 \\
\hline 12 & -7.189565 & 112.780110 & 0.00 & $25-11-20112: 58: 15$ & LoRa1 \\
\hline 13 & -7.217782 & 112.715610 & 0.00 & $27-11-201$ & $17: 05: 58$ & LoRa2 \\
\hline 14 & -7.189565 & 112.780110 & 0.00 & $25-11-201$ & $12: 58: 15$ & LoRa1 \\
\hline 15 & -7.217782 & 112.715610 & 0.00 & $27-11-201$ & $17: 05: 58$ & LoRa2 \\
\hline 16 & -7.189565 & 112.780110 & 0.00 & $25-11-201$ & $12: 58: 15$ & LoRa1 \\
\hline 17 & -7.217782 & 112.715610 & 0.00 & $27-11-201$ & $17: 05: 58$ & LoRa2 \\
\hline 18 & -7.217782 & 112.715610 & 0.00 & $27-11-201$ & $17: 05: 58$ & LoRa2 \\
\hline 19 & -7.189565 & 112.780110 & 0.00 & $25-11-201$ & $12: 58: 15$ & LoRa1 \\
\hline 20 & -7.217782 & 112.715610 & 0.00 & $27-11-201$ & $17: 05: 58$ & LoRa2 \\
\hline
\end{tabular}

In the Table is the result of testing integrated with the multi-client method that is the system receives coordinate data from two Client transceivers where it is seen from the table that alternately the data is received by LoRa reciever then coordinate data is stored in the database server.

\section{CONCLUSIONS RECOMENDATION}

AND

\subsection{Conclusions}

After carrying out the design process and making the application and testing of the position monitoring system for escort personnel with the LoRa / GPS Shield, the following conclusions can be drawn:

a. Digital maps that can be used on this system are maps with .tif or .shp extensions according to Pushidrosal standards.

b. By using a standard antenna, the transmit range reaches $2.09 \mathrm{Km}$ with an average time of two seconds transmitting due to the limitation of sending data in the Client transceiver program.

c. This system is able to receive coordinate data from several Transceiver Client devices with the same protocol and frequency.

\subsection{Recomedation}

Designing a ship monitoring personnel position monitoring system with LoRa / GPS Shield still requires development

recommendations based on the results of the test, as follows:

a. Diperlukan modifikasi sistem agar peta yang digunakan bisa menggunakan ENC (Electrical Navigational Chart).

b. Agar jarak jangkau transmit bisa lebih jauh dapat memodifikasi antenna dengan penguat signal pada Gateway transceiver.

c. Diperlukan modifikasi database server online agar bisa diakses oleh pusat komando darat. 


\section{REFERENCES}

Roger S. Pressman, P. (2002). Software Engineering (Practitioner Approach). Yogyakarta: Andi Publisher.

Kendall E Kenneth and Kendall E Julie. (2006). Systems Analysis and Design. Bandung: PT. Index.

Jeffrey A. Hoffer, Joey F. George, Joseph S. Valacich. (2012). Modern Systems Analysis and Design (Sixth Edition). New Delhi: Pearson Education.

John Burch and Gary Grudnitski. (1986). Information Systems Theory and Practice. New York: John Wiley and Sons

Kiswanto, H., Prasetyo, S., Suprayitno, S., \& Marbandi, A. (2017). Sistem Informasi Rumah Negara Di Lantamal. International Journal Of ASRO STTAL, 7, 1-8. Retrieved from http://asrojournal-

sttal.ac.id/index.php/ASRO/article/view/ 222

Minarto, M., Majid, A., Ahmadi, A., \& Bukit, A. (2017). Rancang Bangun Aplikasi Sistem Pencatat Keluar Masuk Personel Di Penjagaan Sttal Surabaya Berbasis Rfid. International Journal Of ASRO - STTAL, 8, 1-16. Retrieved from http://asrojournalsttal.ac.id/index.php/ASRO/article/view/ 223

Purwito, A., Sitanggang, D., Suprayitno, S., \& Marbandi, A. (2018). Design Of Prison Security Information System Using Rfid. International Journal Of ASRO STTAL, 9(1), 129-135. Retrieved from http://asrojournal-

sttal.ac.id/index.php/ASRO/article/view/ 227
Rozikin, C., Kurnianto, F., Ahmadi, A., \& Syaifi, M. (2018). Design Of Shooting Score Recording Information System Based On Image Processing. International Journal Of ASRO - STTAL, 9(1), 136141. Retrieved from http://asrojournalsttal.ac.id/index.php/ASRO/article/view/ 228

Sulistyono, E., Mahia, F., Bandono, A., \& Syahlan, Z. (2018). Design And Manufacture Of Indonesian Naval Warship Technical Condition Report And Inventory Information System. International Journal OF ASRO STTAL, 9(2), 133-140. Retrieved from http://asrojournalsttal.ac.id/index.php/ASRO/article/view/ 229 